\title{
Religion and the New Media: Discourses and Debates in the 2018 Fiji General Election Campaign
}

\section{https://doi.org/10.33318/jpacs.2020.40(2)-4}

Jacqueline Ryle ${ }^{1}$ and Jope Tarai ${ }^{2}$

\begin{abstract}
This article explores discourses and debates on secularism, religion, and politics in social media in connection with the 2018 Fiji general election campaign, and in interviews with leading figures in churches and religious organisations. It discusses how people responded to these issues. It shows that there is still a pervasive lack of clarity in the Fijian population as to what the terms Christian state, secular state, secularism, and secularisation mean, how people understand, discuss, and debate them, and how this lack of clarity was used politically during the campaign.
\end{abstract}

Keywords: Fiji Elections; New Media; Christian State; Secular State; Secularism

1 Senior Lecturer, School of Social Sciences, The University of the South Pacific, email: jacqueline.ryle@usp.ac.fj

2 Assistant Lecturer, School of Government, Development and International Affairs, The University of the South Pacific, email: jope.tarai@usp.ac.fj 


\section{Introduction}

On 1 August 2018 Fiji residents woke to campaigning billboards across the country stating, "Embrace Godliness. Reject racism and bigotry". "Mmm. New slogan, these things are like riddles", noted one Facebook user (Facebook Post, 2018). "Embrace Godliness"? I thought Fiji was declared a secular state under your government", noted another tweet (Tweet, 2018). ${ }^{1}$ On 1 August 2018 the election campaign was nowhere near underway. The Writ of Elections was not issued until 1 October 2018, yet the posting of this billboard message was, in effect, an unofficial launching of the campaign. Social media feeds and subsequent interviews in late 2018 and 2019 with prominent Fijian religious figures indicated that it was among the most notable of Frank Bainimarama's FijiFirst Party slogans - in terms of generating debate and remaining something people clearly remembered even long after the campaign. As the social media comments and interview statements show, it was effective in so much as it caused surprise, indignation, anger and confusion, as well as connecting at deep levels with many people's faith.

This paper explores discourses and debates on religion and politics in the new media and media in connection with the 2018 Fiji general election campaign. It focuses on a number of specific moments in the debates. These are responses to the 1 August billboard; the Budget Roadshow by FijiFirst, where they stated that "God is in the budget", on 17 August; and Roman Catholic Archbishop Peter Loy Chong's "Preelection homily reflection on economic justice", on 7 October. The paper's timeframe extends beyond the 14 November Election Day to the culmination of negative profiling of Archbishop Loy Chong in the Fiji Sun with the article by Jyoti Pratibha, in which she states, "Archbishop Peter Loy Chong is the biggest loser of the Elections",(Pratibha, 2018), and Archbishop Loy Chong's response to this on Facebook on the same day.

The paper focuses on media, in particular social media discussions of these specific moments in the election campaign, and reflections by leading figures in churches and religious organisations on these themes. We start by discussing the complex and shifting landscape of religion and secularism in Fiji, the rapid development of social media in the country, and the place of political debate in social media as a powerful political force. What the paper shows is the depth of religious complexity in Fiji, the immense differences in perspectives depending on one's religious affiliation and

\footnotetext{
${ }^{1}$ The author clearly assumed the billboard texts emanated from the government. Yet, there was no acknowledgement of source on the billboards - unless, that is, you stood very close to the billboard and could see the small print at the bottom.
} 
experience, and the ways in which these were utilised politically.

\section{Religion and secularisation in Fiji}

Fiji's city and landscapes, interspersed as they are with churches of various denominations, temples, mosques, Hindu prayer flags, crosses, billboards, buses and cars with religious slogans, and the sight of the religious faithful making their way to and from their places of worship, bear witness to the vibrancy of faith practices in everyday life in the country. In the Census of 2007, which provides the most recent available figures on religious affiliation in Fiji, $64.5 \%$ of the population were Christians, 28\% Hindu, and 6.3\% Muslim (Fiji Bureau of Statistics, 2007). The Methodist Church is by far the largest of Fiji's churches, its membership totalling almost $35 \%$ of the whole population at that time. From the mid-1980s until the coup of 2006 the ideal of declaring Fiji a Christian state, closely linked to certain strong factions within the Methodist Church, was debated in several waves. It gained particular political prominence around the time of the May 1987 coup, at subsequent Methodist Church conferences, during the 1995 Constitution Review Commission, from the 2000 coup until the 2006 coup, and again during the 2012 Constitution Review Commission led by Professor Yash Ghai.

Yet, as noted by the late Ratu Joni Madraiwiwi (interview, 2015), this is the agenda of a minority of indigenous Fijians, ${ }^{2}$ as also reflected in the figures noted by White (2017, p. 74) that "of the 7,091 individual submissions logged by the 2012 Constitution Commission, 846 declared in favour of Fiji being a Christian state". ${ }^{3}$ At the same time, the pervasive confusion about what is meant by the term "Christian state" plays into these figures. It is highly unlikely that all submissions in favour of a "Christian state" concerned a de jure one. As Ryle has argued elsewhere, ${ }^{4}$ prior to the adoption of the 2013 Constitution those debates raged between Christian conservative theological perspectives of the exclusivity of Christianity in Fiji, inevitably linked with understandings of indigenous Fijian ethnic superiority, contra inclusive Christian theologies, embracing multicultural ideals and advocating

${ }^{2}$ In 2012, the then-military government changed by decree the designations of different communities in Fiji. The term "Fijian", rather than denoting indigenous Fijians, became the politically correct designation for all Fiji citizens, regardless of their ethnicity. iTaukei (lit. owners) became the term to denote indigenous Fijians. Indo-Fijians retained their denotation, while from 2012 also officially becoming "Fijians". While recognising these official changes, in this paper we use the term "indigenous Fijian".

${ }^{3}$ Similarly, a survey on democratic development in Fiji in 2011 noted a significant lack of interest among respondents to the Christian state issue (Boege et al., 2013, p. 41).

4 (2004; 2005; 2009; 2010; 2015). 
ecumenical and interfaith dialogue among Fiji's ethnic groups.

Since the declaration of Fiji as a secular state in 2013 by the then-military government headed by Frank Bainimarama, the idea of a Christian state has often been viewed as the opposite of the secular state. For many people this is linked with anger and frustration at the way in which the widely accepted 2012 Yash Ghai Draft Constitution, the result of extensive and open consultation, was thrown away by the military government and replaced by decree with the 2013 Constitution.

While Fiji remains a country deeply formed by religious beliefs and practices that are closely interwoven with culture, processes of globalisation are impacting on and changing the former taken for granted, solid place of faith practices in everyday life, particularly in urban contexts.

Rapid economic, political and sociocultural changes within Fiji society since the Second World War are increasingly eroding traditional social structures and social control mechanisms within families, clans and villages, as is migration and increasing seasonal migration, social mobilization and urbanization (Ernst, 2012, p. 36; Ernst, 2006, p. 75). Halapua (2003, pp. 175-176) emphasises how the coups of 1987 and 2000 affected a "breakdown of moral order". And Tomlinson (2013) points out how the Methodist Church's involvement in the 1987 and 2000 coups "seems to have accelerated movement away from the established church and fractured the religious landscape" (Tomlinson \& McDougall, 2013, p. 15). These many changes are challenging the taken for granted status of religion and religious practice in Fijian society. Added to this are the virtual realities accessible through social media that closely link with Western secularism.

The now-increasingly contested secularisation thesis within the study of religion claims that all societies will universally evolve from religious to secular, rational thinking. In secularisation, privatised forms of religion replace public forms, and rational, scientific thinking replaces religious beliefs (Berg-Sørensen, 2013, p. 3). Secularisation also denotes the processual decline of the power and influence of religion and religious institutions in society, meaning that "the lives of fewer people ... are influenced by religious beliefs" (Bruce, 1992, p. 6). Yet, religion has not disappeared from society, even in secularised Western societies, but is changing its form. As Taylor argues, though "the developments of Western modernity have destabilized and rendered virtually unsustainable earlier forms of religious life, new forms have sprung up" in a continuing, complex process of "destabilization and recomposition" (Taylor, 2007, p. 594). The complex, shifting dynamics of 
Christianity in Fiji over the past decades exemplify this, as does the central place of religion in societies across the Pacific Island region, and the increasing role of religion in twenty-first century national and world politics.

At the same time, secularisation has also, Bhargava notes (2013, p. 18), become a political doctrine, claiming the separation of religion and politics as "normative", fixed in content, and timeless. Yet, as Bhargava emphasises (2013, p. 18), there are many different forms of secular state, and each needs to be understood as developing within and pertaining to specific historical, political and sociocultural processes. Fiji's form of secular state is a case in point, arguably styled in response to and in order to restrain and contain religio-ethno-nationalist movements that advocated, especially at the time of the coups of 1987 and 2000, that Fiji be declared a Christian state.

Critics of the Christian state have argued that the ideal is more about power relations than religion. As former Methodist Church President, the late Rev Paula Niukula sharply noted, "The issue of the Christian state has nothing to do with Christianity but rather the strengthening and accumulation of power and wealth by those in power" (Casimira, 30 November 2002). This point was echoed by Winston Halapua, Dean of the Anglican Holy Trinity Cathedral during the 1987 coups. The slogan used by Christian state advocates, noqu kalou, noqu vanua (my God, my land), he wrote, "manipulated a majority of Fijians because of the apparent appeal to the deep cultural values of the Fijians. In reality such a cry was a smokescreen for naked power grabbing and wealth accumulation" (Halapua, 2003, p. 108).

While the 2013 constitutional declaration of Fiji as a "secular state" has shifted the balance of these power relations, the lack of clarity of what it means and entails has created other challenges. Since its inception, the terms "secular", "secularisation" and "secularism" have appeared increasingly in English language use in Fiji among faith groups. However, there is still very little clarity as to what exactly these terms mean, in particular what a secular state is. This lack of explanation at the national level of the new terminology has given rise to the erroneous understanding among many Christians that Fiji has become a secular state.

The often-expressed understanding among Christians in Fiji is that the 2013 Constitution changed Fiji's status from being a Christian state to that of a secular state. Yet Fiji has always been a secular state, even though, as Trnka points out, Sitiveni Rabuka's introduction of the Sunday ban after the second coup he led in 1987, forbidding all non-church related activities, in effect transformed Fiji into a de 
facto Christian state, until the ban was repealed in 1995 (Trnka, 2011, p. 75; see also Trnka, 2008). Christianity was granted special mention in Fiji's previous constitutions and freedom of religion was "a tacit agreement" guaranteed by previous governments though not formerly written into the constitutions (Ratu Joni Madraiwiwi, interview, 2015; Mahendra Chaudhry, interview, 2015; White, 2017). But these facts are far from the general conception of many Christians in Fiji, for whom Fiji's shift to a de jure secular state in 2013 is seen as having deprived them of something existentially precious.

In contrast to this, leading figures from the religions the majority of Fiji Indians belong to see the secular state as legally guaranteeing religious freedom and giving greater protection and reassurance to those of non-Christian faiths. Reflecting on threatening experiences of stones being thrown onto the roofs of houses during prayers, and the burning and looting of temples, Arya Samaj Vedic priest and Interfaith Search Fiji council member Pandit Bhuwan Dutt believes that the constitutional enshrining of Fiji as a secular state gives non-Christian believers greater protection. "[There's] assurance that [should] anyone should disturb you in your prayers, you ... have recourse to the law ... that the law should protect you ... [should there be] any ... misbehaviour against any religion" (interview, July 2019). This was echoed by Mr Sarju Prasad, national president of the Sanatan Dharm Pratinidhi Sabha Fiji, who said, "That was the sunrise for us. We were very happy ... that now there will be less burning of temples" (interview, July 2019).

However, while offering re-assurance and protection to non-Christians, to the majority of indigenous Fijian Christians, the secular state is still confusing. As Methodist Church President Rev Dr Epineri Vakadewavosa expressed it, voicing sentiments other leading figures in churches have also expressed, "From day one up till now many people in the Church do not understand, even the teachers. It's quite difficult to come to terms with secularism and the secular state" (interview, June 2019).

Catholic Archbishop Peter Loy Chong points out that "secular" is a new term for Fiji (Ryle, 2015). There is no Fijian word for this. One translation could be, according to Archbishop Loy Chong, vanua vakavuravura meaning "a worldly country". Another translation could be matanitū sega ni yavutaki e na lotu meaning "a state not based on the Church/Christianity" (Paul Geraghty, pers. comm., March 2020). The translation of "secular state" in the 2013 Constitution (Clause1:4) is matanitu vuravura (a worldly state) (The Republic of Fiji, 2013). To indigenous Fijian Christians all these terms indicate a society devoid of God, of faith and of spirit and 
appear to threaten one's freedom to be a person of faith and to practice one's faith. In fact, these are the very fears that non-Christian believers have lived with for decades due to the political threat of Fiji being declared a Christian state.

Whatever guarantees advocates of the Christian state purport to have for securing freedom of religion (cf., Ryle, 2005, 2010), it is difficult to see how this in effect would be possible, and it is these fears the 2013 Constitution now allays for believers of non-Christian religions. It is notable that, although the Fiji Council of Churches did not agree with the move to constitutionally declare Fiji a secular state, all the historic mainline member churches fully embrace the separation of church and state. ${ }^{5}$ In 2014, Roman Catholic Archbishop Chong sent out a pastoral letter to all parishes emphasising the Catholic Church's position on church and state (Ryle, 2015).

In 2018, President of the Fiji Mission of the Seventh Day Adventist Church Pastor Luke Narabe sent out a letter of ministry to all Adventists, reminding "all church leaders and members about our position as a Church". In the final section of his letter, "Pray for our Nation", he quotes from the Department of Religious Liberty of the General Conference of the Seventh Day Adventist Church:

The Seventh-Day Adventist Church makes its position clear toward politics. 1) It is actively neutral in party politics, 2) It is not neutral in moral issues; 3) It does not dictate how to vote, 4) It stands for separation between church and state ... The Adventist Church welcomes people of all political beliefs. While church members should vote [according to] their conscience [,] for the church to take a position on any particular candidate or political party would inject the church into a debate that would interfere with its spiritual mission (Narabe, 27 September 2019).

Yet when churches express that the terminology surrounding the secular state is unclear, their points of view are often interpreted as being against a secular state and so therefore for a Christian state. The lack of open and informed debate is unfortunate, as it perpetuates and entrenches polarised, stereotypical representations of different positions, simultaneously maintaining a blurred picture and making it

${ }^{5}$ Founded in 1963, the Fiji Council of Churches belongs under the aegis of the World Council of Churches. Member churches are the Anglican Church, Catholic Church, Congregational Church of Samoa, Coptic Orthodox Church, Fiji Baptist Convention, Fiji Community Churches of Christ, Methodist Church in Fiji and Rotuma, Presbyterian Church, Salvation Army. Churches that are not members include the Seventh Day Adventist Church, and Pentecostal churches such as Assemblies of God and Christian Mission Fellowship. 
impossible to explore nuanced perspectives.

To fully grasp the complexities of the Christian state vs secular state debate in Fiji, Ryle has argued at length ${ }^{6}$ that these concepts need to be understood in relation to the so-called Three Pillars of Fijian society, vanua, lotu, and matanitū (see Niukula, 1994, 1997, and Tuwere, 1997, 2002, ${ }^{7}$ both former Methodist Church presidents). Vanua, a complex term of deep existential meaning to indigenous Fijians, encompassing paths of kinship relations, nurture and mutual obligations, connects place, people, pre-Christian gods and spirits and Christian beliefs with the past, the present and the future (Ryle, 2010, xxxix). Lotu means church, faith, Christianity. Matanitū in its pre-colonial meaning, was the most powerful manifestation of divine chiefly governance. From at least 1870 , matanitū has come loosely to be understood as state or government in the Western sense. After Cession to Great Britain in 1874, it came to be equated with colonial governance. However, it never completely lost its perceived connection to chiefly power.

Vanua lotu vāKarisito means "land of the Church", or "land of Christian faith". It also denotes "Christian state", entangling within it all the complexities of vanua. Addressing this confusion, Revd Dr Ilaitia Sevati Tuwere, Methodist Church President (1996-98), who advocated strongly against the Christian state ideal, emphasised in-1998 (Ryle, 2010, p. 58) an important distinction between what he termed vanua vāKarisitō (a Christian land) and matanitū vāKarisitō (a Christian state). Noting that the term "matanit $\bar{u}$ " entails complex legal aspects, he stressed, "we can simply live according to the principles of the Christian faith" (Ryle, 2010, p. 58).

It seems that often, when indigenous Fijians refer to a Christian state, they are not referring to the legal frameworks of a de jure state as such, but to what they perceive as essential: living according to Christian principles and values, embedded as these are within traditional values of vanua. There is therefore lack of clarity as to what people mean when they speak of either a "Christian state" or a "secular state". The terms are used loosely, very rarely defined, yet each continues to engender anxiety in different communities. This paper argues that the lack of clarity was employed politically in the election campaign to fuel this pervasive anxiety. Judging from

${ }^{6}$ (2004, 2005, 2009, 2010, 2015).

7 The Three Pillars is not the same as what is known as "the three-legged stool". This expression, developed by Ratu Sukuna, referred to the mutually dependent ethnic groups of Fiji society during colonialism, the Fijians, the Indians, and Europeans, the Fijians providing the land, Europeans the capital and skilled manpower, and Indians their cheap labour (B. Lal, 1988, p. 60; see also Sukuna, 1983) (Ryle, 2010, p. 55). 
comments made, especially on social media, many people considered that the "God card" was played with a deft hand on several occasions and served to confuse, woo and seduce the electorate.

\section{New Media - Social Media in Fiji}

New media refers specifically to social media in Fiji and its access through digital technologies. In recent years, social media access has expanded dramatically in Fiji due to increasing interconnectivity, competitive internet costs and affordability of digital devices (Tarai, 2019; Tarai et al., 2015; Cave, 2012). Rising social media access has provided greater space for more spirited and at times controversial political discussions. An increase in social media political discussions has become compounded by Fiji's restrictive media landscape, being a symptom of its most recent, 2006 Coup (Tarai, 2019; Tarai, 2018). The continued constraints of Fiji's traditional media landscape have seen a rise in social media discussions and debates on Fiji's politics (Robie, 2016; Singh, 2015; Tarai, 2018). As such, social media has increasingly become an indicator for public discourse on specific issues.

To capture these discussions, two key approaches and tools were utilised and reviewed. First, social media analytics tools ${ }^{8}$ were utilised to extract quantitative data on Fiji's new media landscape and demographics. Certain social networking sites, such as Facebook, actively provide social media analytic data in terms of its "Audience Insights". Second, digital ethnography ${ }^{9}$ was utilised as an iterativeinductive approach in critically examining online discussions informed by contextbased insights and analysis.

A number of social networking sites (SNS) comprise what may be referred to as social media in Fiji. These include but are not limited to Tumblr, Pinterest, Twitter, YouTube, Instagram, and Facebook. Out of these SNS, Facebook is the most populated and popular across Fiji's demographic distribution. In 2018, there were a little over 500,000 estimated Facebook accounts in Fiji (Audience Insights, 2018; Tarai, 2019). Despite the fact that this figure would include multiple accounts that could be owned by one person, it does indicate an extensive audience that is over

${ }^{8}$ Social media analytics tools derive quantitative (and to some extent qualitative) data from social networking sites and have been extensively used in business marketing and specialized academic research (new media/social media, digital technologies, e-governance, etc.).

${ }^{9}$ Digital Ethnography is an iterative-inductive approach to examining and studying online and offline related dynamics, usually through a mediated form of contact (digital technologies) and participant observation (Pink et al., 2016). These dynamics are subject to the context and content of what is being examined and how it is being examined. 
half of Fiji's 884,887 estimated total population (Fiji Bureau of Statistics, 2017). Fiji's Central Division is estimated to have the largest amount of active Facebook accounts, with $68 \%$, followed by the Western Division at $28 \%$, with the Northern Division at 3\%, and 1\% for the Eastern Division (Audience Insights, 2018).

Out of the estimated 500,000 or so active Facebook accounts in Fiji, accounts that have participated in or expressed interest in political and social issues are estimated to number 150,000 to 200,000 (Audience Insights, 2018). This is by no means a surprise since one of Fiji's most controversial and at times highly political Facebook forums, ChatFiji has a little over 200,000 members (Tarai \& Drugunalevu, 2018; Tarai, 2019). This forum has demonstrated the capability to create viral content and propel the public interest, simply because of its extensive Facebook account membership and discussion momentum (Tarai \& Drugunalevu, 2018; Tarai, 2019). In essence, social media expanse and depth is massive and increasingly reflective of the general public's concerns, views and debates.

The explosion of more interactive and pronounced social media political discussions in Fiji can be traced back to 2011, to Facebook forums such as Letters to The Editor Uncensored (LEU) (Tarai, 2019). ${ }^{10}$ These were forums designed as reactions to the ongoing implications of direct censorship in traditional media newsrooms. They accommodated a little over 10,000 accounts at the time, with varied activity over the years. In the lead up to the controversial establishment of the 2013 Constitution in 2012 and 2013, Facebook became a site of rigorous debate and discussions. A wide range of key political and social issues relating to the constitutional process and contents were debated. One of these was the heated debate on the Christian state and secularism. However, the online debates shifted from this to the processes involved when the 2012 constitutional draft came to an abrupt stop, as Fiji Police shredded and burned the finalised copies of the 2012 Draft Constitution (Morris, 2013).

Online debates and discussions on the Christian state and secularism re-emerged in 2014 in the lead up to Fiji's first elections under the newly enforced 2013 Constitution. The 2014 general election was the first election in Fiji's history that saw the involvement of social media (Tarai et al., 2015). Out of all the social media platforms, Facebook was the most populated and active SNS during the 2014 general election. In January 2014, a total of 260,000 estimated Facebook accounts were active in Fiji (Tarai et al., 2015). This figure rose to an estimated 298,000 by the

10 There were online political discussions in 2009, when the 1997 Constitution was abrogated, but these were more limited to blogsite discussions, which were not as prominent and interactive as Facebook political discussions. 
polling month of September 2014 (Tarai et al., 2015), which indicated increasing interest in accessing Facebook specifically for political information, discussion and debates.

Social media was used in campaigning and debating key issues among voters and directly with particular candidates. Most of the online discourse on the Christian state and secularism involved Fiji's biggest opposition party SODELPA and their supporters. SODELPA is composed of Fiji's indigenous conservative elites who have strong views on the ideals of the Christian state and secularism. These debates were limited in scope as they predominantly involved like-minded users who typically expressed similar views, limiting the scope and duration of exchanges.

In the 2018 general election, however, online discourses on the Christian state and secularism were no longer limited to or instigated by opposition parties, but were now initiated by the ruling FijiFirst party. This began with the FijiFirst billboards in August stating, "Embrace Godliness [sic]. Reject racism and bigotry".

\section{"Embrace Godliness [sic]. Reject racism and bigotry" - a memorable slogan}

From January 2018, oversized billboards with jet black backgrounds and an enormous, Fiji-flag blue font with simplistic soundbite slogans became common aspects of roadsides and cityscapes across the main islands of the Fiji group. Examples of some slogans include: "Honesty and Justice; Stability and Equality"; "Youth empowerment and Women's Rights"; "More students in schools and universities than ever before"; "All Fijian Families Matter"; "Reject Lies, Embrace truth". But the message on 1 August 2018 stood out: "Embrace Godliness [sic]. Reject racism and bigotry."

Of all the billboard slogans, this engendered particularly strong responses. The use of "Godliness", employing an unusual capitalisation, was arguably no error but a strategy to ensure the reader made a connection to "God" as in the God of Christianity. ${ }^{11}$ FijiFirst deployed the slogan simultaneously on its two social media platforms, on Facebook and Twitter, from 13-14 August 2018. The majority of FijiFirst supporters lauded the 1 August billboard message on social media, thanking the Prime Minister and the Party for the slogan, stating "FijiFirst the best, God bless FijiFirst" (Facebook Comment, 2018). However, more critical voters questioned the sudden use of religion in FijiFirst's campaign: "Ironic how a secular state uses 'Godliness' in their billboard. Reject hypocrisy!' (Facebook Comment, 2018);

${ }^{11}$ In this paper, we use the spelling "godliness". 
"Confused much from a so called [sic] secular state" (Facebook Comment, 2018) "The billboards accuse all Fijians of being ungodly, racist bigots" (Facebook Comment, 2018). The critical comments gathered increased attention and focus during the campaign because of the confusion that the slogan created.

In contrast to the immediacy and intensity of these social media reactions in August 2018, retrospective responses to the billboard by prominent figures of Fiji's different religions, when interviewed in 2019, were quietly reflective. Despite different definitions of the terminology and different perspectives on the words of the billboard, there was consensus that "embracing godliness" is essential to all religions and religious life. ${ }^{12}$ But there were many different interpretations of the place and use of this religious terminology in the election campaign, and how it worked.

The majority of religious leaders interviewed saw the words of the billboard slogan as fundamental values of individual faith, religious practice and for the good of all society. "We would love to see a government that promotes godly values", Pastor Luke Narabe, President, Seventh Day Adventist Church (SDA), stated (interview, July 2019). "Well, 'embrace godliness' ... that is what the call to holiness is all about, about living in harmony and tolerance with one another", Revd Dr Epineri Vakadewavosa, President, Methodist Church in Fiji and Rotuma noted, continuing:

It's a very profound message. If you want to have a good society, you must have godliness ... They have been mentioning about a secular state, but to value that, is very interesting ... [it] is another way of saying that ... godliness is genuine in a good society (Interview, July 2019).

Revd Dr Tevita Banivanua, President, Fiji Council of Churches (FCC) noted, "I think the billboard was a good one, 'to embrace godliness' and of course to reject in the political sense, racism and bigotry ... was the very thing that we were trying to embrace ... I was happy when I saw that' (Interview, July 2019). To Pandit Bhuwan Dutt, Arya Samaj Vedic Priest, these words were "long overdue":

These are important principles of life which we in Fiji, like anywhere else, should embrace and practise ... it was reassuring ... and people were able to connect to it ... Because ... placing God on top of everything is very important in any process ... because without God, nothing exists. And without godliness human beings won't become good people ... we need to remind our people of

${ }^{12}$ See also Newland, 2016, p. 115 regarding notions of a "godly" government in the 2014 elections, and see Newland, 2007 for discussion of religion in the 2006 elections. 
these very important principles of life (Interview, July 2019).

Head priest, Bhai Preetam Singh Shokar, Sikh Gurudwara Prabandhak Committee, Suva, saw the billboard as reminding people of values common to all religions: "Under godliness, there are all these good deeds; the billboard is just a reminder", adding a universal understanding of the divine: "Ram, Allah, Jesus - means the same" (Interview, November 2018).

Dr Rajesh Maharaj, President, Hari Krishna, pointed out that the words of the billboard "should not just be for the sake of it"; they need to be lived out. He, similarly, saw the message as expressing universal religious values and the universality of God. As he emphasised, "God is neither Hindu nor Christian. God is God" (interview, November 2018). To Sanatan Hindu Pandit, Mr Ramesh Sharma, the billboard slogan was "a wake-up call to see and activate yourself" (interview, November 2018). National President of the Hindu Sanatan Dharm Pratinidhi Sabha, Mr Sarju Prasad, expressed:

To me it means that we want to promote religion in this country and promote secular state and secularism. We want to merge as a society ... reject racism and bring about unity in diversity ... this is a blessing to this country because Fiji is enjoying a very diverse society, diverse traditions and diverse culture and races, and everyone has the freedom to pray their way, act their way and do things, what may be a little alien to other people, within this society ... If this is a genuine statement, I wholeheartedly support this (Interview, July 2019).

The negative commentary in many social media posts indicated that many people found the religious terminology an odd choice and incongruous with the Government's promotion of Fiji as a secular state. But from Sanatan Hindu perspectives, Mr Prasad explained, there is no clash between "godliness" and "secular state", "they complement one another" (Interview, July 2019).

Some interviewees questioned the use of complex and contested terms as "racism" and, in particular, "bigotry" in a billboard slogan. "It's quite a big word, eh? I hope the average people understand", Major Uraia Dravikula, Salvation Army, reflected (interview, July 2019). Some Christian interviewees saw the wording as a politicising of religion:

I thought there was some politicisation of religion there: to 'Embrace Godliness' - that would go well with a lot of people. In Fiji if you're a politician [and] if you don't embrace religion you [will have difficulties]. But how thick is their 
secularism? This secular state ideology seems to be on a theoretical level but in real life that is not happening. They say 'secular state' but in practice religion is still very important in most government institutions (Interview, Archbishop Peter Loy Chong, March 2019).

Major Uraia Dravikula of the Salvation Army, was possibly most emphatic:

You talk about 'embrace Godliness' and you want to take out Christianity from the equation ... Godliness is from God, to embrace Godliness is from God, that's a capital ' $G$ ', it's not a small $\mathrm{g}$. I think it's like a fishing net ... like a drag net: catch the Christians. Because ... the average Christian will ... associate 'Godliness' with the God of Christianity, with Christ ... And yet at the same time ... you are trying to say that this is a secular state ... It's sending out mixed signals to the people. And to me, it makes people angry because it's like somebody's playing a game with them ... You are trying to play the people's emotions (Interview, July 2019).

\section{Responses to "reject racism and bigotry"}

Several Indigenous Fijian Christians interviewed took issue with the "reject racism" part of the slogan. As with many of the social media comments, there was a sense that the slogans were stereotyping, labelling certain sections of the population. Indigenous Fijians expressed a sense of being labelled racist just by virtue of being indigenous Fijians. There was also a sense that the slogan was blowing out of proportion something that was not a major issue in Fiji:

'Reject racism' - to be proud of your own race ... to accept that I'm a Fijian, I'm not being racist ... in myself being a proud Fijian does not mean I am racist ... [or mean] to say that my Fijianness overrides everything. Like I said before [Ryle 2015, p. 44], if my Fijianness goes against the values and the principles of Christianity, of Christ, then I take this Fijianness away ... But the thing is that people twist it. It is only a thin line and they put a broad brush ... It is their own agenda (Major Dravikula, Salvation Army interview, July 2019).

The billboard slogan buys into the debate of whether equality is gained by eradicating any mention of "race" or "ethnicity" contra multicultural approaches to equity by celebrating and protecting diversity:

'Reject racism' meaning Fiji's made up of various racial groups and the Constitution says now we are all Fijians. Therefore, we should realise that by 
rejecting racism and not speaking of any racial categories, all people [are] of God with equal rights, and therefore we need to adjust our thinking (Pandit Dutt, interview, July 2019).

The choice of the term "bigotry" was puzzling to many. There was a general lack of clarity as to its precise meaning. As with "secular" and "secularism", it seems that a new term was introduced into Fiji society with no explanation. "I thought to myself, what would people in the rural areas make of this word?" Anglican Archbishop Emeritus Dr Winston Halapua mused (interview, December 2018). "They probably should have chosen words that were easier to define, from the perspective of others", Rev Dr Banivanua (FCC) pointed out, "but you know for media, these are the words that sparks [sic] the light", he added, emphasising that the same could be said for the use of the term "racism" (interview, July 2019).

The National President of the Hindu Sanatan Dharm Pratinidhi Sabha saw the message as positive, "Reject racism and bigotry": 'I and Sanatan ... strongly support these sorts of remarks ... and billboards ... that serves to strengthen this unity in diversity. But we must understand: race is a fact of life in this country" (Prasad, interview, July 2019). Pandit Dutt reflected, "How does one define bigotry? ... I thought it was too heavy a word for [ordinary] people ... they should have put a simpler word there", he added, suggesting that a positive message might have worked better:

People have different types of belief in God in Fiji ... but the common thread [is] that everybody believes in God, whatever form of God they have ... people have the belief that there's a Creator above us, he's an all-powerful and we need to recognise that ... there are different ways of going to God. There is one God, the same God, but different people believe differently. This word means there's one God there ... It says Godliness, meaning 'you should respect God' ... godliness, be respectful to God, and also do things which are good for everybody

At the same time, he queried:

[But] when you embrace godliness, does it really mean that you do something good, or do you just embrace it? ... Does it mean that you simply say 'Okay, I'm in a secular state, I'll embrace my own God ... and the others are not important?' ... embrace which type of godliness? ... It might have been better [to] say 'Always tell the truth, be friendly to everyone', those things are more important and more understandable to the common people (Pandit Dutt, 
interview, July 2019).

\section{"God is in the Fiji budget": The Budget Roadshow}

In the Budget Roadshow, the Minister for Economy travels from place to place, talking about the budget and what it has to offer the people. On 17 August 2018, the FijiFirst Campaign Facebook page presented a statement by the Minister for Economy who, judging from his wording, must have been responding to a question or critique: "I think it is preposterous to say there's no God in this. I'm sure God also means that we need to look after the poor, the sick and the needy. And that's what this budget provides for. It pays for the needy, for the poor. It gives them insurance. Giving mothers' maternity leave and fathers' paternity leave" (FijiFirst Party, 2018). This moment was when FijiFirst started linking the billboard message with the announcement of the 2018 budget and the Budget Roadshow. The video gathered over 144 reactions, 17 of which "Loved" the video by reacting with the "heart" emoticon. Interestingly, this included the FijiFirst page itself.

Responses from the interviewed religious leaders to this message were mixed. "I'm glad that comes from the Government. It's another way of saying that the secular state that they represent, that ... they are getting the sources of their leadership through God, through Christ", Rev Dr Vakadewavosa, MCF, noted (interview, July 2019). Pandit Dutt was clear:

It is good ... because Fiji is a very God-loving country ... we all believe in God, whatever we do, whatever way we do it, it's still different but we are a Godloving, God-fearing country ... When it says God there, I believe the government is trying to revive the thinking that this is a God-loving country ... you know, the poor and the needy ... if you are reminded about God, you are likely to do the good things (interview, July 2019).

On the one hand, religious leaders saw the inclusion of a reference to God in the budget and linking the budget with God and with the poor as making sense, since from religious perspectives God should be part of how life and society are framed.

To me, it's a balanced approach to the distribution of funds where we also need to look at people who ... are unfortunate, we need to take care of them. I see that there is sense in what he is saying, if we do that. If they are genuine in what they are doing, not only to win hearts of people for the campaign. It should be part of what we need to do because God put the poor and people who are less fortunate than us, who may be around us, also to test us, test our faith ... whether 
we really care - as a nation, as a people, as a Church, as individuals, as families. The people who are around us, we need to take care of them. The Lord also spent most of his time going to villages, healing the sick, healing the blind, healing leprosy. For me I sense a lot of sense in what the Minister of Finance is saying (Pastor Narabe, interview, July 2019).

On the other hand, one Christian interviewee asked, "Which God is [the Finance Minister] referring to?" Many Fijian Christians cannot accommodate within the doctrines of their faith or their own beliefs the concept of a universal God who is defined and addressed differently, depending on one's religion. Another point raised, was that any mention of "God" in Fiji is likely to catch many people's attention. And again, attention was drawn to the incongruence of mentioning God during an election campaign while otherwise strongly advocating Fiji as a secular state:

Most of us, we are more alert ... whenever the name God is mentioned. And to use it in such a way ... is not fair to the concept of God and ... what we believe by the concept of God. [People] revere the concept, and [for it] to be associated with the budget ... Looking after the poor and underprivileged, that's a social thing that any government should do ... presenting their manifestos ... but to use the concept of God needs more explanation.

And at the same time ... the issue of secular state was quite a big challenge, it still is, eh? So, to counter that with the use of God, the word, was sort of bringing in something that they don't believe. I mean ... in the Constitution there is no word about God, about Christianity, and yet they want to use it in their manifesto .... In order to win people, you sell your everything, something like that ... They were looking for words that could move them away from their emphasis, from what they were really trying to do (Rev Dr Banivanua, interview, July 2019).

\section{Roman Catholic Archbishop Peter Loy Chong's "Pre-Election Homily Reflection on Economic Justice" (7 October 2018)}

As mentioned earlier, during the 2014 Election campaign Catholic Archbishop Peter Loy Chong sent out an Episcopal Pastoral Letter that was read out at Mass in all parishes, emphasising the Catholic doctrinal position on the separation of church and state. "The Church must remain independent of any particular political or economic system", he wrote, at the same time noting the importance of Catholics bringing together religious principles and values in voting (Ryle, 2015, p. 40). In a similar vein in the 2018 election campaign, the Archbishop sought to inform and educate the Catholic faithful on five core issues of Catholic social teaching: social justice, family 
life, education, domestic violence, and ecological justice. As in his Episcopal Pastoral Letter of 2014, in the 2018 election campaign, Archbishop Loy Chong emphasised that his purpose was not to instruct the Catholic faithful whom to vote for or against, but to encourage well-informed individual political conscience and responsibility in voting. His idea was to circulate a sermon on each of these central topics among his clergy for five weeks to be read out at Mass. Catholic faithful in all parishes across Fiji would thereby receive the same foundation for making a decision at the ballot box, solidly informed by Catholic religious principles.

The first sermon, "Pre-Election Homily Reflection on Economic Justice", was to be read out on Sunday, 7 October 2018. Solidly founded on biblically-based, Catholic social teaching on economic justice, it emphasised concerns about rising levels of poverty in Fiji. It focused on the moral dimensions of economic life and the Catholic Church's vision of divine worth, noting "Our Catholic social teaching teaches that a fundamental moral measure of any economy is how the poor and vulnerable are faring" (Chong, 2018). As such, poverty levels and their impact on the most vulnerable become a moral measure of an economy. In expressing this, Archbishop Loy Chong drew on statistics on poverty by Professor Waden Narsey from 20042005 and 2010-2011. The sermon also highlighted that taxation in 2006 had burdened the poor in Fiji.

This created a firestorm of media responses, spearheaded by Jyoti Pratibha in the pro-Fijifirst government's newspaper, Fiji Sun. Archbishop Loy Chong was accused of sharing false information based on out-of-date data. The matter galvanised public opinion and debate. Two key letters in the Fiji Times "Letters to the Editor" section in October 2018 amplified the two sides in the ongoing debate. At one end, critics argued that Chong was too political. This was evident in a letter by vocal FijiFirst party supporter and religious critic, Mr Simon Hazelman from Savusavu. In his 6 October letter, he argued that the major Christian Churches such as the Methodist and Catholic Church "should not get involved in politics" and must "remain consumed with worship, praise and blessing" (Hazelman, 2018). In a 9 October letter, Mr Hazelman furthermore argued that, “....in Fiji poverty is nothing more than a choice".

Challenging this view, Mr Kositatino Tikomaibolatagane from Navua argued that sentiments such as those of Mr Hazelman were "shallow" because, he maintained, Christ himself "...stood up to be the voice of truth and justice challenging political power structures" (Tikomaibolatagane, 2018). Interviewed religious leaders fully supported Chong's speaking out on social inequality and social justice in his sermon. 
"Peter was on the right track", Major Dravikula said: "You cannot leave the poor behind. To march with progress, you must march with the marginalised", he emphasised (interview, July 2019). "We are together with Peter at Fiji Council of Churches", the President of Fiji Council of Churches stated:

To help the poor is to awaken their life to the goods that are around them, it's not spoon-feeding ... Fr Barr ${ }^{13} \ldots$ when he was in ECREA (Ecumenical Centre for Research, Education and Advocacy) every year when the budget comes, there was a shadow budget that comes with it from [the] angle [of the poor] and it almost destroyed the emphasis of that other budget (Rev Dr Banivanua, interview, 2019).

President of the Methodist Church, Rev Dr Vakadewavosa expanded on the prophetic role of the churches in society:

We cannot divorce ourselves from the society, we are part of the society. The church is part of society, Christ himself was born in society ... the mission of the church is a mission in society, in the community ... that is the basic role of the church - to bring the love of God to the people, to be well-versed in what the people are confronting ... The church must be very well versed with what is happening in society and the church walks along with the government of the day. At the same time the church has the freedom to speak on behalf of God on anything that is perhaps incorrect in society, in the care and the life of the people, the role of the government, the church has the right to speak the truth about what the people are facing and call the government to respond accordingly - whether they like it or not. That is the responsibility of the church. Give to Caesar what is Caesar's, give to God what is God's. We walk alongside the government; we respect the rule of law (interview, July 2019).

Responding to the criticism vented against him, Archbishop Loy Chong apologised for using poverty figures from 2008, which his critics deemed out of date. At the same time, however, he emphasised that social issues such as poverty in Fiji should and must remain a concern in the election (Bolanavanua, 2018).

But the issue did not end there. The Prime Minister also used the accusations against the Archbishop at a campaign rally in Nasinu to a predominantly non-Christian

${ }^{13}$ Australian Catholic missionary, the late Fr Kevin Barr (1936-2020) played a strong role over almost four decades in Fiji as advocate of the poor. As part of his many endeavours to raise awareness of and fight for social injustice and the alleviation of poverty, he.t, co-founded and directed the NGOs ECREA and People's Community Network. 
audience. He stated:

The Christian State will be tied to the Christian but we don't know what Christian denomination is going to take over, whether it's going to be the Methodist, whether it's going to the Catholic. You've heard what the Catholic Archbishop is saying he is all wrong, so you might end up listening to somebody who has been listening to somebody who is giving you wrong stats all the time. That's what's going to happen if you turn this place into a Christian State (Talei, 2018).

In effect the Prime Minister further discredited Archbishop Loy Chong by linking him to the ideal of the Christian state. This is particularly ironic since the Catholic Church in Fiji has long been the most vocal church in speaking out against the Christian state ideal (Ryle, 2005, 2010).

Right after the election, Fiji Sun journalist Jyoti Pratibha continued her personal attacks on Archbishop Loy Chong, labelling him as one of the election's "Biggest Losers" (Pratibha, 16 November 2018). The same day, Chong posted an unequivocal response on his Facebook page, labelling Pratibha's writing as "fake news" because in it she claimed that "he came under fire from his own flock" (Chong, 16 November 2018). Rebutting this, Chong stated that he had "the full support from key bodies within the Catholic Church", emphasising his prophetic role as Archbishop under the Pope to speak out on social injustice.

Government and pro-government media organisations aggressively targeted religious leaders such as Archbishop Loy Chong. It was evident that the social justice messages of Catholic social teaching were perceived as political threats during the campaigning period. In addition, they exposed the Government's weak record on socio-economic issues, repeatedly raised by economists.

\section{Conclusion}

This paper has discussed complexities of religion and the new media during the 2018 Election campaign. We focus on certain key moments during the campaign when religious messages were accentuated in different media contexts, interweaving immediate reactions to these on social media at the time with retrospective reflections by religious leaders interviewed in late 2018 and 2019.

FijiFirst clearly employed a campaign strategy of regularly referring to "God" and "religion". Several religious leaders intimated that campaign references to God and 
religion demonstrate recognition on the part of the Government of the central importance of God in Fijian society. They agreed that the values espoused in the religious slogans and phrases were universal values that all well-functioning societies should be based on. However, their views on the actual use of religious slogans and phrases in the campaign differed, depending on their religious affiliation. Hindu leaders were those who viewed the billboards most positively.

Among indigenous Fijian Christian leaders, the lack of clarity as to the meanings of the terms secular state, secularism and secularisation was accentuated. They found it puzzling and incongruous that a government that strongly promotes these ideals could simultaneously use God and religion in campaign slogans and debates. A notable number of social media postings also focused on this.

Our findings suggest that this lack of clarity and confusion was employed as a political strategy to create controversy and attention in campaigning. In the 2018 general election, discourse on secularism, religion and politics was closely guarded and manoeuvred to create a moral political position for the government on "religious freedom". This was posited against the straightjacketing of opposition parties within a politics of the past. Ironically, religious freedom was somewhat limited for leaders such as Archbishop Peter Loy Chong, who sought to emphasise Catholic social teachings on social justice in relation to the economy.

A nuanced and open discourse could help build trust within the nation. But discourse on secularism, religion and politics in the 2018 general election was strictly defined and determined by the ruling government. Ultimately, this strategy kept the discourse unclear, constrained within static and unnuanced oppositional narratives, polarising political perspectives. This is expedient as a source of moral political capital and in maintaining power but offers few options for moving forward as a nation.

\section{References}

Audience Insight. (2018). Facebook Analytic - Chat Fiji - online activity, s.l.: Facebook.

Audience Insights. (2018). Facebook Audience Insights - Fiji. [Online] Available at: https://www.facebook.com/ads/audienceinsights/people $?$ act $=265873366 \&$ age $=18-\&$ country $=$ FJ

Bainimarama, V. (2018). Friday 7pm FBC News 19-10-18 - Secular State, Suva: FBC News

https://www.facebook.com/fijibroadcastingcorporation.news/videos/329 
Bainimarama, V. (2018). Speech by Hon Josaia Voreqe Bainimarama, Prime Minister of Fiji at the USP Open Day on Friday 27 July 2018. [Online] Available at: https://www.usp.ac.fj/index.php?id=22497

Berg-Sørensen, A. (2013). 'Introduction'. In Berg-Sørensen, A. (ed) Contesting Secularism: Comparative Perspectives. Farnham: Ashgate.

Bhargava, R. (2013). 'Multiple Secularisms and Multiple Secular States'. In BergSørensen, A. (ed) Contesting Secularism: Comparative Perspectives. Farnham. Ashgate.

Bolanavanua, S., 2018. Archbishop Apologises for Wrong Figures. [Online] Available at: https://fijisun.com.fj/2018/10/09/archbishop-apologisesfor-wrong-figures/

Boege, V., Casimira, A., Ernst, M., Szesnat, F. (2013). Voices of the People: Perceptions and Preconditions for Democratic Development in Fiji. Suva. Pacific Theological College.

Bruce, S. (1992). Religion and Modernization: Sociologists and Historians Debate the Secularization Thesis. Oxford: Clarendon Press.

Casimira, A. (2002). 'A Fundamentalist Christian State', Fiji Times 30/11/02: 7.

Casimira, A. (2008). Who Do You Say I Am? Interaction between Bible and Culture. Suva: ECREA.

Cave, D. (2012). Digital Islands: How the Pacific's ICT revolution is transforming the region, Sydney: Lowy Institute.

Chong, P. L. (2018). Catholic Vision for the Economy, Suva: Fiji Times Online.

Chong, P. L. (2018). 'Fake News' and 'Researched News', Suva: Archbishop of the Catholic Church in Fiji - Released Statement on the 16th of November 2018.

Chong, P. L. (2018). Unpublished Pre-Election Homily Reflection On Economic Justice. Suva: Sacred Heart Cathedral.

Ernst, M. (2006). 'Globalisation Processes in the Pacific Islands'. In Ernst. M. (ed) Globalization and the Re-shaping of Christianity in the Pacific Islands. Suva: Pacific Theological College: 58-78.

Ernst, M. (2012). 'Changing Christianity in Oceania: a Regional Overview'. In Fer, Yannick (ed) Special Issue, Archives des Sciences Sociales des Religions: Changing Christianity in Oceania, Janvier-mars 2012, no.157: 29-45. Paris: Èditions de l'École des Hautes Études en Sciences Sociales.

Facebook Comment. (2018). FijiFirst the best, God bless FijiFirst'. [Online] Available at: https://docs.google.com/document/d/1iSAJy7RVcsHNOHxF6sanwvbZF Q7YzhjCJkXxUby6BWs/edit 
Facebook Comment. (2018). "Confused much from a so called secular state". [Online] Available at: https://docs.google.com/document/d/1EdcsmXHBtMCQRuRnQROt84as uAtevjMyFM_8d_bitq8/edit

Facebook Comment. (2018). "Ironic how a secular state uses 'Godliness' in their billboard. Reject hypocrisy!". [Online] Available at: https://docs.google.com/document/d/1oktM6W_vzW1GK91CDCnsIFPEl NPAJeigLfpyBgOLg9c/edit

Facebook Comment. (2018). "The billboards accuse all Fijians of being ungodly, racist bigots". [Online] Available at: https://docs.google.com/document/d/1JVfsD_ZCi0wFWEZgb4hlPO38k83t9Ky93ymK0R7BWU/edit

Facebook Post. (2018). "Mmmm. New Slogan, these things are like riddles". [Online] Available at: https://docs.google.com/document/d/1NDKg07QVD_SKHK41155I0p3Qh6R21KnWSSLWc-7L8k/edit

Fiji Bureau of Statistics. (2007). Population by Religion, Suva: Fiji Bureau of Statistics - Fiji Government.

Fiji Bureau of Statistics. (2017). Census 2017 of Population \& Housing, Suva: Fiji Bureau of Statistics.

FijiFirst Party. (2018). God is in the Fiji Budget. [Online] Available at: https://www.facebook.com/watch/?v=1874433489292826

Halapau, W. (2003). Tradition, Lotu and Militarism in Fiji. Lautoka: Fiji Institute of Applied Studies.

Hazelman, S. (2018). Cautious Vote. (Letter to the Editor) In Fiji Times, 9 October 2018: p. 9.

Lal, B. (1988). Power and Prejudice: the Making of the Fiji Crisis. Wellington: New Zealand Institute of International Affairs.

Minges, M. \& Stork, C. (2015). Economic and Social Impact of ICT in the Pacific, Sydney: Pacific Region Infrastructure Facility.

Morris, R. (2013). What now for the people's constitution. Suva: Republika Magazine.

Narabe, L., n.d. Pastoral Letter dated 27 September 2018 from Seventh Day Adventist President in Fiji, Pastor Luke Narabe, to Ministers, Teachers, Church workers, Church Elders, Church Members, Fiji Mission. Copy in possession of J. Ryle. Excerpt printed here by kind permission of Pr Narabe.

Narsey, W. (2014). Facts on Poverty and Social Justice. [Online] Available at: https://narseyonfiji.wordpress.com/2014/07/27/the-facts- 
on-poverty-and-social-justice-the-fiji-times-26-july-2014/

Newland, L. (2007). 'The Role of the Assembly of Christian Churches in Fiji in the 2006 Elections'. In Fraenkel, J, and Stewart Firth (eds) From Election to Coup in Fiji - the 2006 Campaign and its Aftermath. Canberra. ANU Press, pp. 300-314.

Newland, L. (2016). 'From the Land to the Sea: Christianity, Community and State in Fiji - and the 2014 Elections', in Ratuva. S. and Lawson, S. (eds) The People Have Spoken, pp. 109-133.

Niukula. P. (1994). The Three Pillars: The Triple Aspect of Fijian Society. Suva: Christian Writing Project.

Niukula. P. (1997). Religion and the State. In Lal, B.V. \& T. R. Vakatora (eds) Fiji in Transition. Research Papers of the Fiji Constitution Review Commission Vol.1: 53-79. Suva: School of Social and Economic Development, University of the South Pacific.

Pink, S., Horst, H., Postill, J., Hjorth, L., Lewis, T. \& Tacchi, J. (2016). Digital Ethnography: Princiles and Practice. Los Angeles: SAGE.

Pratibha, J. (2018). Analysis: The Big Winners, Losers and No Surprises. [Online] Available at: https://fijisun.com.fj/2018/11/16/analysis-the-big-winnerslosers-and-no-surprises/

Rabuka, S. (1999). The Fiji Islands In Transition: A Personal Reflection. Canberra ACT: s.n.

Rabuka, S. (2018). Monday 7pm FBC News 22-10-18 - Secular State, Suva : FBC News

https://www.facebook.com/fijibroadcastingcorporation.news/videos/297 $\underline{455897760708 /}$

Robie, D. (2016). 'Unfree and unfair'?: Media intimidation in Fiji's 2014 elections. In: The People Have Spoken. Canberra: ANU Press, pp. 83-108.

Robie, D. \& Perrottet, A. (2011). Pacific Media Freedom 2011: A status report. Pacific Journalism Review, pp. 148-186.

Ryle , J. (2004). 'Religion: Tro, Tradition, Politik' [Religion: Faith, Tradition, Politics]. In Hastrup. K. (ed) Viden om Verden: en Grundbog om Antropologisk Analyse. [Knowledge of the World: A Text Book on Anthropological Analysis]. Copenhagen: Hans Reitzel, pp. 259-279.

Ryle, J. (2005). Roots of Land and Church: The Christian State Debate in Fiji. International Journal for the Study of the Christian Church - Routledge, pp. 58-78.

Ryle, J. (2009). 'Les Chemins de la Foi et du Pouvoir: Christianisme, Tradition et Politique à Fidji' [Paths of Faith and Power: Christianity, Tradition and 
Politics in Fiji]. In Fer, Y. \& G. Malogne-Fer (eds), Anthropologie du

Christianisme en Océanie, Cahiers du Pacifique Contemporain $\left(\mathrm{n}^{\circ} 4\right)$.

Paris: L'Harmattan, pp.73-101.

Ryle, J. (2010). My God, My Land: Interwoven Paths of Christianity and Tradition in Fiji. Farnham: Ashgate.

Ryle, J. (2015). Religion, the Christian State and the Secular State - Discourses during the 2014 Fiji General Election campaign. The Journal of Pacific Studies, pp. 35-48.

Singh, S. (2015). FIJI: The evolution of media laws in Fiji and impacts on journalism and society. Pacific Journalism Review: Te Koakoa, pp. 126-141.

Sukuna, R.L. (1983). Fiji: The Three Legged Stool, edited by Deryck Scarr. London : Macmillan Education.

Talei, A. (2018). Fiji to stay secular state: Bainimarama. [Online] Available at: https://www.fbcnews.com.fj/news/fiji-to-stay-secular-statebainimarama/

Tarai, Finau, G., Titifanue, J. \& Kant, R. (2015). Political Social Media Campaigning in Fiji's 2014 Elections. Journal of Pacific Studies, pp. 89-114.

Tarai, J. (2015). To Regulate or Not: Fiji's Social Media. [Online] Available at: https://www.academia.edu/16277346/To_Regulate_or_Not_Fiji_s_Socia $\underline{1 \text { Media }}$

Tarai, J. (2018). 2018 Fiji elections: the real losses and wins. [Online] Available at: https://www.academia.edu/38032885/2018_Fiji_elections_the_real_loss es_and_wins

Tarai, J. (2018). Unpacking Fiji internet law narratives: Online safety or online regulation?. Pacific Journalism Review: Te Koakoa, pp. 84-94.

Tarai, J. (2019). Controlling the Internet in Fiji. [Online] Available at: https://www.academia.edu/38200495/Controlling the_Internet_in_Fiji

Tarai, J. (2019). Social Media and Fiji's 2018 National Elections (Forthcoming). Pacific Journalism Review.

Tarai, J. \& Drugunalevu, E. (2018). Citizen Journalism, Social Media \& The Media in Fiji. [Online] Available at: https://www.academia.edu/37664738/CitizenJournalism_Social_Media_ and the Media_in_Fiji

Tarai, J., Finau, G., Titifanue, J. \& Kant, R. (2015). Fiji Flag Change: Social Media Responds. [Online] Available at: https://www.academia.edu/16277346/To_Regulate_or_Not_Fiji_s_Socia $\underline{1 \text { Media }}$

Taylor, C. (2007). A Secular Age. Cambridge, Massachusetts, and London, England: 
The Belknap Press of Harvard University.

Tikomaibolatagane, K. (2018). Political Right. (Letter to the Editor) In Fiji Times, 9

October 2018: p. 9.

Tomlinson, M. (2013). 'The Generation of the Now: Denominational Politics in

Fijian Christianity'. In Tomlinson, M. And D. McDougall (eds) Christian

Politics in Oceania. New York: Berghahn: 78-102.

Tomlinson, M. \& McDougall, D. (2013). 'Introduction: Christian Politics in

Oceania' In Tomlinson, M. And D. McDougall (eds) Christian Politics in

Oceania. New York: Berghahn: 1- 21.

The Republic of Fiji. (2013). Constitution of The Republic of Fiji Retrieved from

https://www.laws.gov.fj/ResourceFile/Get/?fileName=2013\%20Constitu tion\%20of\%20Fiji\%20(iTaukei).pdf

Trnka, S. (2008). State of Suffering: Political Violence and Community Survival in Fiji. Ithaca \& London: Cornell University Press.

Trnka, S. (2011). Re-Mythologising the state. Public security, 'the Jesus-strategy' and the Fiji Police. In Oceania 81: 72-81.

Tuwere, I.S. (1997). 'The Church-State Relation in Fiji' In Lal. B. and T. Vakatora (eds) Fiji in Transition, Research Papers of the Fiji Constitution Review Commission Vol. 1: 43-52. Suva: School of Social and Economic Development. University of the South Pacific.

Tuwere, I.S. (2002). Vanua: Towards a Fijian Theology of Place. Suva: Institute of Pacific Studies, University of the South Pacific and College of St John the Evangelist.

Tweet. (2018). "Embrace Godliness"? I thought Fiji was declared a secular state under your government". [Online] Available at: https://docs.google.com/document/d/1ZbcHw0nXEKDOSDAk8i0wINX RYmwGRdPPklDaF8Sgews/edit

White, T.A.J. (2017). How novel is the secularism of Fiji's 2013 Constitution?' Journal of South Pacific Law, pp. 73-100.

Youth \& Sports. (2018). Youth \& Sports - Strategic Plan 2018-2022 (Ministry of Youth \& Sports). [Online] Available at: http://www.youth.gov.fj/images/images/Strategic\%20Plan\%202nd\%20N ov.pdf 


\section{Personal Communication}

Dr Paul Geraghty, The University of the South Pacific, personal communication to Ryle concerning Fijian translation of 'secular state', March 2020.

\section{Interviews conducted}

All interviews conducted by Jacqueline Ryle

For their time and valuable contributions, we thank:

The late Ratu Joni Madraiwiwi, March 2015

Mr Mahendra Chaudhry, March 2015

Pandit Vigyan C. Sharma, Treasurer, Sanatan Dharm Pratinidhi Sabha, November 2018

Mr Khaioum Khan, Fiji Muslim League, November 2018 Archbishop Emeritus Dr Winston Halapua, Anglican Church of Aotearoa, New Zealand and Polynesia, December 2018

Archbishop Dr Peter Loy Chong, Roman Catholic Archdiocese of Suva, March 2019 Revd Dr Tevita Banivanua, President, Fiji Council of Churches (FCC), July 2019 Major Uraia Dravikula, Salvation Army, July 2019

Pastor Luke Narabe, President, Seventh Day Adventist Church (SDA), July 2019 Revd Dr Epineri Vakadewavosa, President, Methodist Church in Fiji and Rotuma, July 2019

Pandit Bhuwan Dutt, Vedic priest, Arya Samaj, July 2019

Mr Sarju Prasad, National President, Hindu Sanatan Dharm Pratinidhi Sabha, July 2019

Dr Rajesh Maharaj, President, Hari Krishna, November 2019

Bhai Preetam Singh Shokar, Sikh Gurudwara Prabandhak Committee, November 2019 